\title{
ANALYSIS OF URANIUM GEOCHEMISTRY IN INDIAN GROUNDWATERS WITH A UNIFIED THERMODYNAMIC MODEL
}

\author{
SURYA SUJATHAN $^{1} *$ AND ABHAS SINGH ${ }^{1}$
}

${ }^{1}$ Dept. of Civil Eng., Indian Institute of Technology Kanpur, U. P., India 208016 (*Correspondence: suryaj@iitk.ac.in)

Widespread pollution of Indian groundwater resources with uranium ( $\mathrm{U}>30 \mu \mathrm{gL}^{-1}$; WHO limit) has been reported. With no known anthropogenic sources, it is unclear what the mechanisms and sources of $U$ release are. This study aims to evaluate the potential drivers of $U$ release in natural aquifer systems through geochemical analysis of published field data. Thermodynamic calculations were made using a carefully compiled internally consistent database of uraniumbearing minerals, aqueous inorganic and organic complexes, redox species, and their associated reactions and stability constants.

Non-parametric Kendall rank test and probability-based association technique ${ }^{[1]}$ indicated that most of the $U$ contamination was localised within $70-80 \mathrm{~m}$ below the surface. U was positively associated with total alkanity, total dissolved solids, $\mathrm{Ca}, \mathrm{Mg}$, and $\mathrm{Fe}$. Out of 6873 locations analysed, 132 were selected for detailed geochemical analyses as the reported solute data satified electroneutrality. Groundwaters at most of the locations were undersaturated with respect to relevant uranium solids, except uraninite $\left(\mathrm{UO}_{2(\mathrm{~s})}\right)$, which exhibited saturation indices between 2.723 and -0.732 at few locations (Figure 1). The Stockholm humic model was used for locations that reported high dissolved organic matter (OM; taken as fulvic acids (FA) and humic acids (HA)). U-OM complexes were estimated to predominate $\mathrm{U}$ speciation for $\mathrm{pH}<5.5$. However, prevalence of $\mathrm{U}-\mathrm{CO}_{3}$ species at alkaline $\mathrm{pH}$ possibly prevents formation of these complexes due to electrostatic repulsion and/or steric hindrance. Also, at the median $\mathrm{pH}(=7.1) \mathrm{Ca}, \mathrm{Mg}$, $\mathrm{Fe}(\mathrm{III}), \mathrm{Zn}, \mathrm{Fe}$ (II), $\mathrm{Na}$, and $\mathrm{K}$, were predicted to have a decreasing order of affinity towards HA/FA.

Figure 1. Variation of uraninite saturation indices (secondary axis) and predicted $\mathrm{U}$ aqueous complexes (primary axis) with $\mathrm{pH}$. U aqueous complexes are predited as $\%$ for a median TOTU $_{\text {diss }}=6.91 \times 10^{-8} \mathrm{M}$ in the presence of

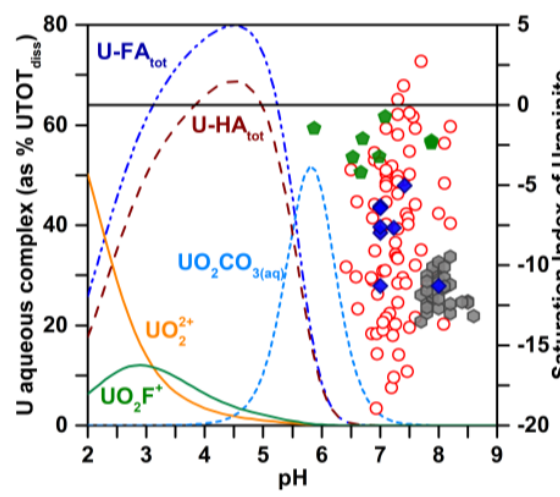

OM taken either as FA or HA

[1] Riedel \& Kubeck (2018), Water Res 129, 29-38 